\title{
COMPARISON OF THE PREVALENCE OF GENES CODING FOR ENTEROTOXINS, EXFOLIATINS, PANTON-VALENTINE LEUKOCIDIN AND TSST-1 BETWEEN METHICILLIN-RESISTANT AND METHICILLIN-SUSCEPTIBLE ISOLATES OF STAPHYLOCOCCUS AUREUS AT THE UNIVERSITY HOSPITAL IN OLOMOUC
}

\author{
Jaromir Sila, Pavel Sauer*, Milan Kolar
}

\begin{abstract}
Department of Microbiology, Faculty of Medicine and Dentistry, Palacky University and University Hospital, Olomouc, Czech Republic

e-mail: pavel.sauer@email.cz
\end{abstract}

Received: October 1, 2009; Accepted: July 1, 2009

Key words: Staphylococcus aureus/MRSA/Virulence factors/Real-time PCR

Aims: Staphylococcus aureus is an important pathogen characterised by its potential to express many virulence factors. Currently, special attention is being paid to methicillin-resistant strains of $S$. aureus (MRSA). The aim of this study was to compare the prevalence of 13 selected virulence factor genes in methicillin-resistant versus methicillinsusceptible $S$. aureus (MSSA) isolates and to investigate their accumulation in the same isolate.

Methods: Real-time PCR was used to detect the presence of genes in 200 isolates of S. aureus (100 MRSA and 100 MSSA) from the University Hospital Olomouc collected in 2005-2006.

Results: Six out of the 13 monitored genes were detected more frequently in MRSA isolates: sea, seb, seg, sei, sej and eta, coding for the production of the enterotoxins A, B, G, I, J and the exfoliative toxin A. On the other hand, the $p v l$ and $t s t$ genes coding for Panton-Valentine leukocidin and TSST-1 were more frequent in MSSA. Statistical analysis (chi-squared test) of the prevalence of virulence factors in the two groups showed a significant difference $(\mathrm{P}<0.05)$ in two cases (seg, sei).

Conclusions: A higher prevalence of selected virulence genes was not confirmed in the methicillin-resistant $S$. aureus group. This indicates no further increase in their threat.

\section{INTRODUCTION}

Staphylococcus aureus is a much feared nosocomial pathogen. For infections caused by this species, the drugs of choice are beta-lactam antibiotics (in particular methicillin and oxacillin). However, increasing resistance to these drugs has recently raised the concerns of both microbiologists and clinicians, especially in the case of methicillin-resistant strains (MRSA). Methicillin resistance is characterized by the presence of the mec $A$ gene coding for modified transpeptidases (penicillin-binding proteins 2a, PBP2a) with very low affinity to beta-lactam antibiotics ${ }^{1}$.

The ability of $S$. aureus to cause various infections and intoxication, results from the production of different extracellular and surface virulence factors with adhesive properties to a range of molecules (MSCRAMMs) ${ }^{2,3}$. The extracellular products include especially toxins with superantigenic properties, namely enterotoxins A-E, G-K, M-O and Q (sea-seq genes), exfoliative toxins A and B (eta, etb), toxic shock syndrome toxin-1 (TSST-1, tst) as well as, for example, Panton-Valentine leukocidin $(p v l)^{4-7}$.

The most common staphylococcal cell wall proteins have affinity to fibrinogen (clumping factors $\mathrm{A}$ and $\mathrm{B}$ encoded by the clfA, clfB genes), fibronectin ( $f n b \mathrm{~A})$, collagen ( $c n a)$, sialoprotein $(b b p)$ and elastin $(e b p \mathrm{~S})$; in the other proteins, the function is as yet unknown $(s d r \mathrm{C}$, $s d r \mathrm{E})^{8-14}$. Experimental models have shown that expression of receptors for fibrinogen and fibronectin is usually associated with staphylococcal endocarditis whereas the presence of adhesins for sialoprotein, collagen and fibronectin is more common in staphylococcal arthritis and osteomyelitis ${ }^{12,15,16}$.

The aim of this study was to compare the presence of genes of selected virulence factors in a group of methicillin-resistant and methicillin-susceptible isolates of S. aureus.

\section{MATERIALS AND METHODS}

\section{Staphylococcus isolation}

A total of 200 isolates of $S$. aureus were collected. Of these, 100 cases were MRSA, the other half were methicillin-susceptible (MSSA). All were obtained from clinical samples of patients in the University Hospital in Olomouc, collected in 2005-2006. Clinical samples were mostly skin and wound swabs, samples from respiratory tract, blood cultures, catheters, urine, tissue and others. Species identification of staphylococci was carried out by standard microbiological methods using the commercially available STAPHYtest 16 set (Pliva-Lachema Diagnostika). Susceptibility to methicillin was determined by the microdilution method (CLSI). In resistant isolates, 
Table 1. Primers used for detection of virulence factors.

\begin{tabular}{|c|c|c|c|}
\hline Primer & Sequence & $\begin{array}{l}\text { Product size } \\
\text { (bp) }\end{array}$ & Reference \\
\hline $\begin{array}{l}\text { mecA-F } \\
\text { mecA-R }\end{array}$ & $\begin{array}{l}5^{\prime} \text {-TCCAGATTACAACTTCACCAGG-3' } \\
5^{\prime} \text { '-CCACTTCATATCTTGTAACG-3' }\end{array}$ & 162 & 18 \\
\hline $\begin{array}{l}t s t-\mathrm{F} \\
t s t-\mathrm{R}\end{array}$ & $\begin{array}{l}\text { 5'-GCTTGCGACAACTGCTACAG-3' } \\
5^{\prime} \text {-TGGATCCGTCATTCATTGTTAT-3' }\end{array}$ & 559 & 19 \\
\hline $\begin{array}{l}p v l-\mathrm{F} \\
p v l-\mathrm{R}\end{array}$ & $\begin{array}{l}5^{\prime} \text { '-ATCATTAGGTAAAATGTCTGGACATGATCC-3' } \\
5^{\prime} \text {-GCATCAASTGTATTGGATAGCAAAAGC-3' }\end{array}$ & 433 & 20 \\
\hline $\begin{array}{l}\text { sea-F } \\
\text { sea- } \mathrm{R}\end{array}$ & $\begin{array}{l}5^{\prime} \text {-GCAGGGAACAGCTTTAGGC-3' } \\
5^{\prime} \text {-GTTCTGTAGAAGTATGAAACACG-3' }\end{array}$ & 521 & 19 \\
\hline $\begin{array}{l}\text { seb-F } \\
\text { seb-R }\end{array}$ & $\begin{array}{l}5^{\prime} \text {-ACATGTAATTTTGATATTCGCACTG-3' } \\
5^{\prime} \text {-TGCAGGCATCATGTCATACCA-3' }\end{array}$ & 667 & 21 \\
\hline $\begin{array}{l}\sec -\mathrm{F} \\
\sec -\mathrm{R}\end{array}$ & $\begin{array}{l}5^{\prime} \text { '-CTT GTA TGT ATG GAG GAA TAA CAA-3' } \\
5^{\prime} \text {-TGCAGGCATCATATCATACCA-3' }\end{array}$ & 284 & 19 \\
\hline $\begin{array}{l}\text { sed-F } \\
\text { sed-R }\end{array}$ & $\begin{array}{l}\text { 5'-GTGGTGAAATAGATAGGACTGC-3' } \\
5^{\prime} \text {-ATATGAAGGTGCTCTGTGG-3' }\end{array}$ & 385 & 19 \\
\hline $\begin{array}{l}\text { see-F } \\
\text { see- } \mathrm{R}\end{array}$ & $\begin{array}{l}5^{\prime} \text {-TACCAATTAACTTGTGGATAGAC-3' } \\
5^{\prime} \text {-CTCTTTGCACCTTACCGC-3' }\end{array}$ & 171 & 19 \\
\hline $\begin{array}{l}\text { seg-F } \\
\text { seg-R }\end{array}$ & $\begin{array}{l}5^{\prime} \text { '-CGTCTCCACCTGTTGAAGG-3' } \\
5^{\prime} \text {-CCAAGTGATTGTCTATTGTCG-3' }\end{array}$ & 328 & 19 \\
\hline $\begin{array}{l}\text { sei-F } \\
\text { sei-R }\end{array}$ & $\begin{array}{l}5^{\prime} \text {-CAACTCGAATTTTCAACAGGTACC-3' } \\
5^{\prime} \text {-CAGGCAGTCCATCTCCTG-3' }\end{array}$ & 466 & 19 \\
\hline $\begin{array}{l}\text { seh-F } \\
\text { seh-R }\end{array}$ & $\begin{array}{l}5^{\prime} \text {-CAACTGCTGATTTAGCTCAG-3' } \\
5^{\prime} \text {-GTCGAATGAGTAATCTCTAGG-3' }\end{array}$ & 360 & 19 \\
\hline $\begin{array}{l}\text { sej-F } \\
\text { sej-R }\end{array}$ & $\begin{array}{l}5 \text { '-CATCAGAACTGTTGTTCCGCTAG-3' } \\
5 \text { '-CTGAATTTTACCATCAAAGGTAC-3' }\end{array}$ & 142 & 19 \\
\hline $\begin{array}{l}\text { eta-F } \\
\text { eta- } \mathrm{R}\end{array}$ & $\begin{array}{l}\text { 5'-GCAGGTGTTGATTTAGCATT-3' } \\
5^{\prime} \text { '-AGATGTCCCTATTTTTGCTG-3' }\end{array}$ & 93 & 22 \\
\hline $\begin{array}{l}e t b-\mathrm{F} \\
e t b-\mathrm{R}\end{array}$ & $\begin{array}{l}5 \text { '-ACAAGCAAAAGAATACAGCG-3' } \\
5 \text { '-GTTTTTGGCTGCTTCTCTTG-3' }\end{array}$ & 226 & 23 \\
\hline
\end{tabular}

Table 2. Frequency of selected virulent factors in percent and the P-values (chi-square test or Yates' chi-square test*).

\begin{tabular}{|c|c|c|c|c|c|c|c|c|c|c|c|c|c|}
\hline & $p v l$ & $e t a$ & $e t b$ & $s e a$ & $s e b$ & $s e c$ & sed & see & seg & seh & sei & sej & tst \\
\hline MRSA & 0 & 10 & 0 & 12 & 3 & 2 & 17 & 0 & 77 & 0 & 77 & 17 & 2 \\
\hline MSSA & 3 & 3 & 0 & 7 & 1 & 9 & 8 & 0 & 49 & 0 & 49 & 8 & 6 \\
\hline P & $0.244^{*}$ & $0.085 *$ & 1.000 & 0.227 & $0.312 *$ & $0.062 *$ & 0.054 & 1.000 & 0.00007 & 1.000 & 0.00007 & 0.054 & $0.127 *$ \\
\hline
\end{tabular}

PBP2a was detected by latex agglutination (Denka Seiken, Japan) and the mecA gene by PCR ${ }^{17,18}$.

In PCR detection of genes responsible for the ability to produce selected virulence factors, positivity was verified using reference strains from the Czech Collection of Microorganisms in Brno ( $S$. aureus CCM 5756 - for enterotoxin A, CCM 5757 - enterotoxin B, CCM 5971 enterotoxin C, CCM 5973 - enterotoxin D, CCM 5972 - enterotoxin E, CCM 7058 - exfoliatins A and B) and strains provided by Dr Petráš from the National Institute of Public Health in Prague (strains for enterotoxins E, G, H, I and J, TSST-1 and Panton-Valentine leukocidin).

\section{DNA isolation}

The isolated staphylococci were cultured on blood agar (Becton-Dickinson) for 24 hours. Subsequently, one colony was removed and resuspended in $100 \mu$ of sterile deionized water and incubated at $99^{\circ} \mathrm{C}$ for 15 mins with gentle shaking in the Thermomixer comfort (Eppendorf) device. Centrifugation followed (1006 g, 5 mins) and the supernatant containing extract of staphylococcal DNA was transferred into new test tubes and frozen for later PCR amplification.

\section{PCR amplification}

To detect the presence of 13 genes coding for the presence of virulence factors ( $t s t, p v l$, eta, etb, sea, sec, sed, seg, sei, seh, sej, seb and see), real-time PCR was selected. Sequences of the primers used as shown in Table 1 have been published by other authors ${ }^{19-23}$. The $25-\mu$ reaction mix contained $5 \mu$ l of $10 x$ reaction buffer $(100 \mathrm{mM}$ of Tris$\mathrm{HCl}, \mathrm{pH} 8.8,500 \mathrm{mM}$ of $\mathrm{KCl}, 1 \%$ Triton X-100, $15 \mathrm{mM}$ of $\mathrm{MgCl}_{2}$ ) $0.4 \mu \mathrm{l}$ of dNTPs ( $10 \mathrm{mM}$ ); 50 pmol of primers, $2.5 \mathrm{U}$ of Taq polymerase, $2.5 \mu \mathrm{l}$ of LC Green and $1 \mu \mathrm{l}$ of 
bacterial DNA (dNTPs produced by Promega, USA; LC Green by Idaho Technologies, USA; other components by Top-Bio, Czech Republic). Amplification was carried out in the Rotor-Gene 6000 thermocycler (Corbett Research, Australia). Initial denaturation of DNA at $94^{\circ} \mathrm{C}$ for $5 \mathrm{mins}$ was followed by another 40 cycles at $94^{\circ} \mathrm{C}$ for $10 \mathrm{~s}$, annealing $\left(56^{\circ} \mathrm{C}\right.$ for $t s t, p v l$, sea, seg, sei, seh, sej or $\left.58^{\circ} \mathrm{C}, 20 \mathrm{~s}\right)$ and elongation $\left(72^{\circ} \mathrm{C}, 40 \mathrm{~s}\right)$ and finally $5 \mathrm{mins}$ at $72^{\circ} \mathrm{C}$.

In control strains, the size of PCR products of individual primer pairs was verified by agarose gel electrophoresis $(2 \% \mathrm{w} / \mathrm{v})$, compared with a DNA marker (200-1500 bp, Top-Bio, Czech Republic). Additionally, high-resolution melting analysis (HRMA) of the PCR product was performed in each amplification of a control strain and products of the tested staphylococcal isolates were then compared with the melting curve.

\section{RESULTS AND DISCUSSION}

The frequency of the studied genes and the chi-squared (or Yates' chi-square) values for the two groups of isolates are summarised in Table 2. The most frequent genes were seg and sei, coding for enterotoxins G and I (MRSA $77 \%$, MSSA $49 \%$ ) and the difference in frequency in the two groups was statistically significant $(\mathrm{P}<0.05)$. In this study, they were always present together and this accords with their previously detected localisation together with other genes - sem, sen and seo - in the same egc cluster ${ }^{24,25}$. The frequency agrees with the data of Peacock et al. ${ }^{26}$ who reported detection of seg in $55 \%$ and sei in $52 \%$ of invasive strains and Becker et al. ${ }^{27}$ who similarly found a prevalence in $55 \%$.

The sea gene was present in $12 \%$ of MRSA and $7 \%$ of MSSA, i.e. less frequently than earlier described prevalence of strains isolated from blood and nasal specimens $(16 \%)^{27}$, and nasal specimens from healthy people $(20 \%)^{19}$. However, the findings are comparable to those reported by the University Hospital in Magdeburg, Germany $(10.9 \% \text { of MSSA })^{28}$.

Other genes for the studied extracellular virulence factors were present significantly less frequently. The $s e j$ gene for enterotoxin $\mathrm{J}$ was always detected together with the gene for enterotoxin D, in $17 \%$ of MRSA and $8 \%$ of MSSA. Becker et al. ${ }^{27}$ reported the isolation of S. aureus with the sej gene from blood in $11 \%$, Layer et al. ${ }^{28}$ in $15 \%$.

Enterotoxin B (seb) was detected less frequently: in $3 \%$ of MRSA and in $1 \%$ of MSSA. The results are comparable to detection of $s e b$ in $3 \%$ of strains from blood ${ }^{27}$, but lower than those published by Peacock et al. ${ }^{26}$ (7\% of carrier strains, $9 \%$ of invasive strains) as well as by Monday et $a l^{19}$.

The sec gene for enterotoxin $\mathrm{C}$ was detected in $2 \%$ of MRSA and $9 \%$ of MSSA. Similar studies reported its detection in $9 \%$ and $14 \%$ of staphylococci isolated from blood and nasal specimens, respectively ${ }^{27}$ or in $11 \%$ and $10 \%$ of carrier and invasive strains, respectively ${ }^{26}$.

The seh gene was not detected in any group of isolates; however, it was reported in $15 \%$ of invasive and in $18 \%$ of carrier strains by Peacock et $a l .{ }^{26}$ and in $5 \%$ of strains by Becker et al. ${ }^{27}$.

The absence of the see gene in the studied groups corresponds with the findings of both Peacock et al. ${ }^{26}$ and Becker et $a l^{27}$.

The eta gene was detected more frequently - in $10 \%$ of MRSA and $3 \%$ of MSSA - than by Becker et al. ${ }^{27}$ ( $1 \%)$. Another type of staphylococcal exfoliative toxin, etb-encoded, was not detected at all and this agrees with Peacock et al. ${ }^{26}$ showing that $22 \%$ of invasive strains carried eta but no etb.

The $t s t$ gene was present less frequently ( $2 \%$ of MRSA and $6 \%$ of MSSA) than in the work by Becker et al. ${ }^{27}$, who reported $t s t$ in $18 \%$ of strains from blood and $22 \%$ of strains from nasal specimens.

The gene coding for Panton-Valentine leukocidin $(p v l)$ was not detected at all in the MRSA group and it was present in $3 \%$ of MSSA. It was reported in $5 \%$ by Holmes et $a l .{ }^{29}$. Higher detection of $p v l-15 \%$ of MRSA collected in 2002 - was described by Wannet et al. ${ }^{30}$. No MRSA isolate with $p v l$ in studied group is delectable information, because of present spread of these dangerous MRSA clones in the Czech Republic.

\section{CONCLUSION}

The prevalence of virulence genes detected by realtime PCR was consistent with that assessed by end-point $\mathrm{PCR}^{31}$. Of the 13 studied genes, 7 were detected more frequently in MRSA isolates: sea, seb, sed, seg, sei, sej and eta, coding for the production of enterotoxins A, B, D, G, I, J and the exfoliative toxin A. On the other hand, the $p v l$, tst and $s e c$ genes for Panton-Valentine leukocidin, TSST- 1 and enterotoxin C were more frequent in MSSA. Statistical analysis of the comparison of the prevalence of virulence factors in the two studied groups using the chi-square test showed a significant difference $(\mathrm{P}<0.05)$ in detection of the seg and sei genes. In the studied group of clinical isolates of $S$. aureus, none exhibited prominent accumulation of virulence factors that would increase its danger (especially in the case of MRSA). The proportion of different genetic elements (that means variaety of strains) detected in various patients was higher - it predicates good epidemiological situation (without massive clonal spread of dangerous strains) in the University Hospital in Olomouc. Finally, the overall prevalence of virulence factors corresponds with that seen in other European countries.

\section{Abbreviations: MRSA, MSSA, TSST-1, MSCRAMMs}

\section{ACKNOWLEDGEMENTS}

The study was supported by grants IGA NR/9065-3 and MSM6198959223. 


\section{REFERENCES}

1. Chambers HF. Methicillin resistance in staphylococci: Molecular and biochemical basis and clinical implications. Clin Microbiol Rev 1997; 10:781-791.

2. Foster JT. Staphylococcus aureus: Extracellular toxins. In: Boulnois GJ, Griffin G, Hormaeche CE, Keusch G, Levine MM, Smith H, Williams PH and Sussman M, editors. Molecular Medical Microbiology. Washington: Academic press; 2002, 843-5.

3. Patti JM, Allen BL, McGavin MJ, Höök M. MSCRAMM mediated adherence of microorganisms to host tissues. Annu Rev Microbiol 1994; 48:585-617.

4. Bohach GA, Fast DJ, Nelson RD, Schlievert PM. Staphylococcal and streptococcal pyrogenic toxins involved in toxic shock syndrome and related illnesses. Crit Rev Microbiol 1990; 17:251-272.

5. Arbuthnott JP. Bacterial cytolysins (membrane-damaging toxins) In: Cohen P. and van Heyningen S., editors. Molecular actions of toxins and viruses. London: Elsevier Biomedical Press; 1982, $107-$ 129.

6. Bhakdi S, Tranum-Jensen J. Alpha-toxin of Staphylococcus aureus. Clin Microbiol Rev 1991; 55:733-751.

7. Prevost G, Cribier B, Couppie P, et al. Panton-Valentine leucocidin and gamma-hemolysin from Staphylococcus aureus ATCC 49775 are encoded by distinct genetic loci and have different biological activities. Infect Immun 1995; 63:4121-4129.

8. McDevitt D, Nanavaty T, House-Pompeo K, et al. Characterization of the interaction between the Staphylococcus aureus clumping factor (ClfA) and fibrinogen. Eur J Biochem 1997; 24:416-424.

9. Eidhin D, Perkins S, Francois P, et al. Clumping factor B $(C l f B)$, a new surface-located fibrinogen-binding adhesin of Staphylococcus aureus. Mol Microbiol 1998; 30:245-257.

10. Jonsson K, Signas Ch, Muller HP, Lindberg M. Two different genes encode fibronectin binding proteins in Staphylococcus aureus: The complete nucleotide sequence and characterization of the second gene. Eur J Biochem 1991; 202:1041-1048.

11. Speziale P, Raucci G, Visai L, et al. Binding of collagen to Staphylococcus aureus Cowan 1. J Bacteriol 1986; 167:77-81.

12. Tung H, Guss B, Hellman U, et al. A bone sialoprotein-binding protein from Staphylococcus aureus: A member of the staphylococcal Sdr family. Biochem J 2000; 345:611-619.

13. Park PW, Rosenbloom J, Abrams W, et al. Molecular cloning and expression of the gene for elastin-binding protein $(\mathrm{ebpS})$ in Staphylococcus aureus. J Biol Chem 1996; 26:15803-15809.

14. Josefsson E, McCrea KW, Ni Eidhin D, et al. Three new members of the serine-aspartate repeat protein multigene family of Staphylococcus aureus. Microbiology 1998; 144:3387-3395.

15. Johansson A, Flock JI, Svensson O. Collagen and fibronectin binding in experimental staphylococcal osteomyelitis. Clin Orthop 2001; 382:241-246.

16. Cheung AL, Wolf C, Yeaman MR, Bayer AS. Insertional inactivation of a chromosomal locus that modulates expression of potential virulence determinants in Staphylococcus aureus. J Bacteriol 1995; 177:3220-3226.
17. CLSI. Performance standards for antimicrobial susceptibility testing; seventeenth informational supplement 2007; M100-S17.

18. Oliveira DC, De Lencastre H. Multiplex PCR strategy for rapid identification of structural types and variants of the mec element in methicillin-resistant Staphylococcus aureus Antimicrob Agents Chemother 2002; 46:2155-2161.

19. Monday SR, Bohach, GA. Use of multiplex PCR to detect classical and newly described pyrogenic toxin genes in staphylococcal isolates. J Clin Microbiol 1999; 37:3411-3414.

20. Lina G, Piemont Y, Godail-Gamot F, et al. Involvement of PantonValentine leukocidin - producing Staphylococcus aureus in primary skin infections and pneumonia. Clin Infect Dis 1999; 29:1128-32.

21. Løvseth A, Loncarevic S, Berdal KG. Modified multiplex PCR method for detection of pyrogenic exotoxin genes in staphylococcal isolates. J Clin Microbiol 2004; 42:3869-3872.

22. Lee CY, Schmidt JJ, Johnson-Winegar AD, et al. Sequence determination and comparison of the exfoliative toxin A and toxin B genes from Staphylococcus aureus. J Bacteriol 1987; 169:3904-3909.

23. Jackson MP, Iandolo, II. Sequence of the exfoliative toxin B gene of Staphylococcus aureus. J Bacteriol 1986; 167:726-728.

24. Jarraud S, Peyrat MA, Lim A, et al. A highly prevalent operon of enterotoxin gene forms a putative nursery of superantigens in Staphylococcus aureus. J Immunol 2001; 166:669-677.

25. Mempel M, Lina G, Hojka M, et al. High prevalence of superantigens associated with the egc locus in Staphylococcus aureus isolates from patients with atopic eczema. Eur J Clin Microbiol Infect Dis 2003; 22:306-309.

26. Peacock SJ, Moore CE, Justice A, et al. Virulent combinations of adhesin and toxin genes in natural populations of Staphylococcus aureus. Infect Immun 2002; 70:4987-4996.

27. Becker K, Friedrich AW, Lubritz G, et al. Prevalence of genes encoding pyrogenic toxin superantigens and exfoliative toxins among strains of Staphylococcus aureus isolated from blood and nasal specimens. J Clin Microbiol 2003; 41:1434-1439.

28. Layer F, Ghebremedhin B, König W, König B. Heterogeneity of methicillin-susceptible Staphylococcus aureus strains at a German university hospital implicates the circulating-strain pool as a potential source of emerging methicillin-resistant $S$. aureus clones. J Clin Microbiol 2006; 44:2179-2185.

29. Holmes A, Ganner M, McGuane S, et al. Staphylococcus aureus isolates carrying Panton-Valentine leucocidin genes in England and Wales: Frequency, characterization and association with clinical disease. J Clin Microbiol 2005; 43:2384-2390.

30. Wannet WJB, Spalburg E, Heck MEOC, et al. Emergence of virulent methicillin-resistant Staphylococcus aureus strains carrying Panton-Valentine leucocidin genes in The Netherlands. J Clin Microbiol 2005; 43:3341-3345.

31. Sauer P, Síla J, Štosová T, et al. Prevalence of genes encoding extracellular virulence factors among meticillin-resistant Staphylococcus aureus isolates from the University Hospital, Olomouc, Czech Republic. J Med Microbiol 2008; 57:403-410. 